\author{
Alla Mamay, \\ Sumy State University, Ukraine \\ Iuliia Myroshnychenko, \\ Ph.D., Associate Professor, Sumy State University, Ukraine \\ ORCID ID, 0000-0002-0463-0347 \\ email: myroshnychenko@management.sumdu.edu.ua \\ Henryk Dzwigol, \\ Doctor of Economics, Professor, Silesian University of Technology, Gliwice, Poland \\ (iD) ORCID ID: 0000-0002-2005-0078 \\ email: henryk.dzwigol@poczta.fm
}

Correspondence author: myroshnychenko@management.sumdu.edu.ua

\title{
MOTIVATION MANAGEMENT MODEL AND PRACTICAL REALIZATION WITHIN THE HEALTH CARE INSTITUTIONS
}

Abstract. The motivation of medical workers is essential to society since the quality of their work affects the individual and public health. The authors highlighted the special role of state and municipal authorities in motivating medical professionals. The study aims to identify the main directions and elaborate the recommendations to build motivational management models in health care facilities. The study reveals the essence and objectives of personnel policy management in health care facilities. The main methods of motivating health workers were analyzed. The authors evaluated the impact of health reforms on health workers' motivation. The study proposed several ways to improve the motivational management models. The authors conducted an in-depth analysis of economic and noneconomic motivation in health care facilities. The methodological basis of the study is comparative analysis, the method of scientific abstraction, induction and deduction analysis, and synthesis. The practical implementation involved the online services Google Ngram Viewer and SciVal. The findings proved the need to develop the health care quality performances and their approval at the local level. The authors concluded that it is necessary to elaborate on a local program of employees' motivation of utility non-profit enterprises to implement qualitative indicators. This program may include the mayor's award, awards free internship programs, invitations to cultural events, symbolic gifts, etc. The obtained results showed that the health reform didn't cover all activity areas of the health care institutions while the funding for medical care per one patient was insufficient. Therefore, the study emphasized the urgency to solve the above strategic problem in state and municipal management in Ukraine. The findings could be useful for the state and the municipal government of Ukraine in elaborating on motivation programs for health workers and their maintenance.

Keywords: motivation model, health care institutions, reforming, management, health workers.

Introduction. Under current conditions, the health sector ensures the enforcement of the constitutional rights to health care, medical care, and health insurance. Thus, the motivation of medical staff increases its relevance. Indeed, the quality performance of medical duties guarantees individual and public health. Vavylov (2014) noted that vocational choice is a basis to form the main motives of medical staff. The findings showed that most health workers are motivated by several factors such as medicine interest - 54.1\%; a desire to be helpful to society - 29.3\%; family tradition - $13.4 \%$; randomness in choosing a profession $-2 \%$. The above indicates that medical professionals increase their consciousness.

As health worker is increasingly motivated by internal factors, their characteristics are advanced. The medical staff increases the sense of duty, responsibility, passion for their work, loyalty to the medical oath. It stands to mention that while the older medical workers are internally motivated, the younger generation

Cite as: Mamay, A.,Myroshnychenko, lu., \& Dzwigol. H. (2021). Motivation Management Model and Practical Realization Within the Health Care Institutions. Health Economics and Management Review, 2, 23-30. http://doi.org/10.21272/hem.2021.2-03

23 
needs external support to pursue a medical career. Besides, they should be provided with a fair material incentive. This study aims to identify the main directions and recommendations for building motivational management models in health care facilities.

Literature Review. The complicated working conditions of medical staff worsening with the COVID19 pandemic actualize the research on developing and implementing new motivational management models in health care facilities. Notably, the word frequency analysis on «motivation» and «healthcare» by the online search engine Google Ngram Viewer confirmed the statement above (Fig. 1-2).

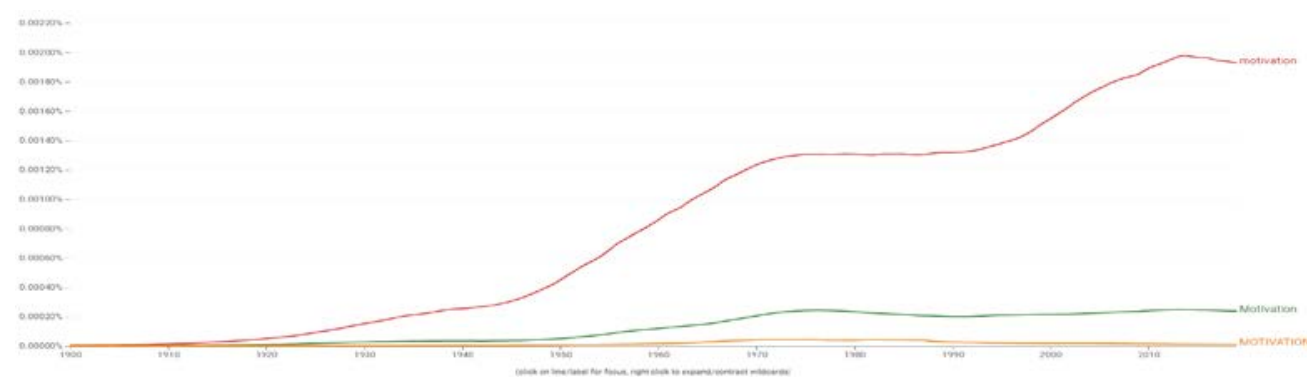

Figure 1. The word frequency analysis on «motivation» (1900-2019)

Sources: developed by the authors using Google Ngram Viewer.

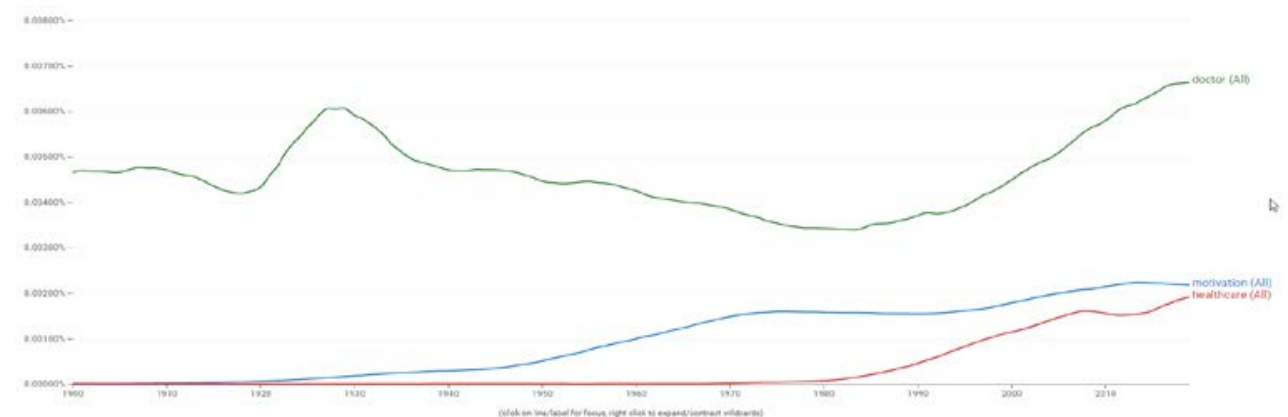

Figure 2. The word frequency analysis on «motivation, healthcare, doctor» (1900-2019) Sources: developed by the authors using Google Ngram Viewer.

For investigating new approaches to work motivation in healthcare facilities, this study explored the international scientific background using the online service SciVal. The research focused on the research area «organizational behavior and human resource management». Figure 3 visualizes the obtained results. Therefore, the in-depth analysis indicated the importance of considering work motivation in health care facilities through social cognitive career theory, career adaptability, and motivation of health workers under the crisis.

It stands to note that job satisfaction and motivation are increasingly recognized as the most critical factors in achieving effective health care outcomes, especially concerning patient satisfaction. Therefore, if the quality and efficiency of medical services are closely connected to the human factor, there is a need to introduce tools to assess and improve the motivation of medical staff. In turn, healthcare facilities could provide quality service if their employees are persuaded that they are valuable resources. Furthermore, in this case, the medical staff is more attentive to the needs of patients. 


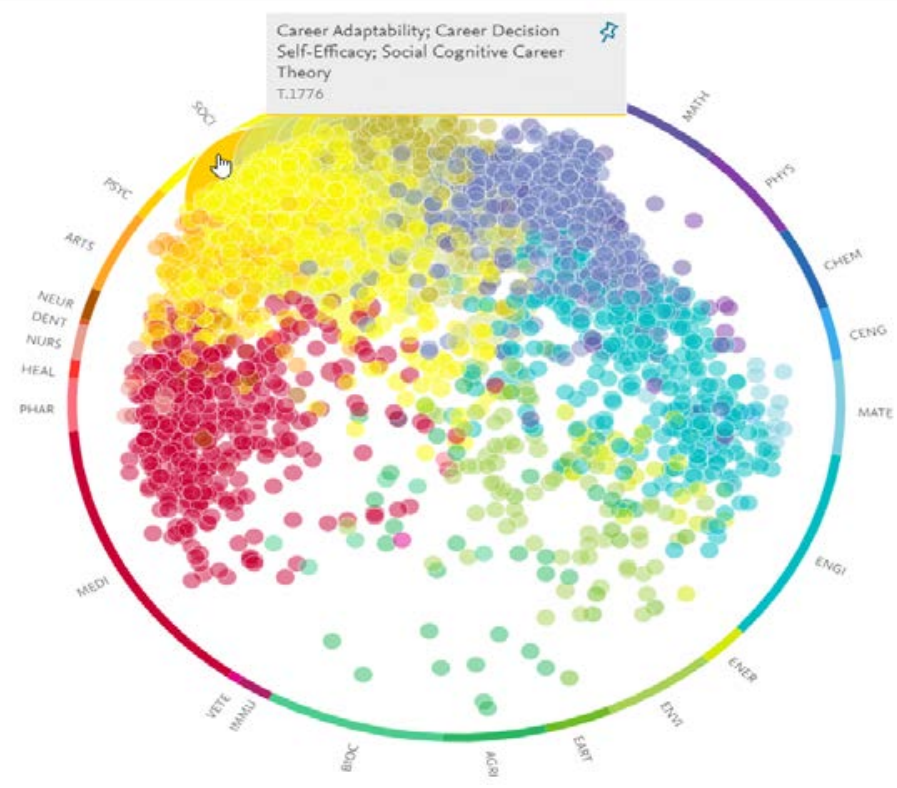

Figure 2. The research area «organizational behavior and human resource management» Sources: developed by the authors using SciVal.

The motivation of health care workers depends on many factors and individual, organizational, and cultural characteristics (Korlén et al., 2017; McDonald and Spence, 2016). Kjellström et al. (2017) considered the motivation of health professionals under health care reform at the national and local levels. In the study, the authors considered the culture of non-hierarchy, teamwork, the atmosphere of kindness, and satisfaction from each other's to be the crucial factors in improving healthcare facilities' work motivation. In turn, the individual factors relate to the health care workers' motivation to care for patients, appreciation of the value of their work, the agreement on the professional and personal goals (McDonald et al., 2007; Toode et al., 2011). At the organizational level, significant motivational incentives are job placement and safety, professional autonomy, team cooperation, positive teamwork, senior professional staff, different work tasks, and financial working conditions (salary, bonus system, and social package) (Razee et al., 2012; Tynan et al., 2013). Luu et al. (2019) empirically proved that leadership directly impacted team performance in health care facilities. Thus, it is a factor of collective motivation.

Valdez and Nichols (2014) conducted a literature analysis on the best practices in motivating medical staff under crisis or emergency. The authors concluded that the operational planning at all levels of the health sector management is a strategically correct decision to provide a sufficient professional. The findings showed that in case of emergencies, work motivation of health professionals might not rest on the sense of responsibility or obligation. On the other hand, health workers are often isolated from society during crises. Besides, they are stigmatized by the nature of their work risk. Preventing absenteeism of health staff could be the biggest challenge. In turn, the motivation theories could help build programs designed to provide an adequate health workforce in a disaster, such as Vroom's Expectancy Theory (Vroom, 1964).

The systematization of scientific studies on motivation models showed that the emphasis lays on introducing measures to ensure preferential access of health workers and their families to preventive medication, examinations, additional services; monetary compensation for difficult working conditions; 

Care Institutions

creating a network of constant psychological support to resolve the internal conflict of the health worker between his family and professional responsibilities.

In this study, the authors conducted the on-depth of theoretical justification and determination of the main directions and recommendations for building motivational management models in health care facilities of Ukraine during the pandemic COVID-19.

Methodology and research methods. The methodological basis of this study is the following data processing methods such as comparative analysis, the method of scientific abstraction, induction and deduction, analysis, and synthesis. The practical part of the investigation involved the Google Ngram Viewer online search engine, and SciVal international research analysis service were used to analyze the subject of the research

Results. Notably, in Ukraine, the funding gap in the health sector has been for many years. In turn, the medical workers were paid a wage by the subvention from the state to local budgets. The medical staff labor cost was calculated under the tariff grid. Due to financial difficulties, many health workers were forced to work part-time, which did not affect the quality of their work. Moreover, they could work out of the medical profession, which negatively impacted their qualifications.

Following the mentioned above, the reformation of the Ukrainian health sector at the state level is aimed, mainly, at eliminating the deformed system, which is unable to provide the necessary list of quality and affordable medical services; building a completely new approach to deliver medical services and effective administration of health care facilities; updating and following the modern standards of material and technical equipment; ensuring the public access to medical services, expressed in the ability to freely choose highly specialized doctors and centralize the full range of medical services.

It stands to mention that the Semashko system rests on the state funding the health care sector under strict centralized management and state control. Herewith, the mentioned above system is substituted with a market model. This model provides health care managers to determine the range of services to be developed independently, use of funds, and allow municipal and state health care institutions to compete with private institutions on quality and high-tech medical services, patient comfort in the institution, and amount of remuneration, etc.

Indeed, the wage is one of the main motivational factors aimed at performance quality. Therefore, one of the reform directions is to increase wages for employees. It should be noted that opinion poll results showed that most medical workers keep hold of their job despite the low wages and partial satisfaction with working conditions. In turn, it indicates that most health workers are characterized by dedication, sustainability of the chosen place of work, a high level of social competence. Undoubtedly, these qualities should be valued and encouraged.

Figure 1 visualizes the systematization of the main motivational factors for health professionals.

\begin{tabular}{|l|l|}
\hline 1 & Sence of being benefit and work value (perception of social significance) \\
\hline 2 & $\begin{array}{c}\text { Sense of moral feel-good (possibility to do the favorite occupation, good social and } \\
\text { psychological work conditions) }\end{array}$ \\
\hline 3 & $\begin{array}{c}\text { Various forms of involvement (proficiency estimation by authority, testimonial, } \\
\text { memorable gift, public gratitude, etc.) }\end{array}$ \\
\hline 4 & $\begin{array}{c}\text { - Advanced training and study (possibilities to participate in the conferences, } \\
\text { symposiums, international traineeships, etc.) }\end{array}$ \\
\hline
\end{tabular}

Figure 3. Motivational factors for medical staff

Sources: developed by the authors. 
Recently, the medical workers were mainly motivated by internal factors. On the other hand, the external factors, except for the social significance of the professional activity, were not effective enough. It stands to mention that the motivation of medical staff mostly addressed to their personal qualities such as responsibility, sense of duty, medical oath, and passion for work. However, the external state stimulation was insufficient. Even though the older generation of health workers are strongly motivated by internal factors, the younger generation needs external support in their medical profession. Moreover, it is essential to provide financial support relating to their work performance.

Under the National Health Service of Ukraine, the health reform provides the calculating the medical remuneration based on the number of health declarations. Indeed, this concept was effective at the beginning of the reformation since creating a patient base for doctors. The patient was the object of the doctor's efforts. Therefore, signing the declaration was to get the remuneration. The medical staff was motivated to get more money due to more signed declarations. However, primary health care reform and maintaining the health care system and motivating health workers is human health. Notably, the main efforts of the family doctor, therapist, and pediatrician should be aimed at timely diagnosis and disease prevention. Therefore, nowadays, there is a need to introduce the special indicators of medical care quality at the state level and establish an institution to monitor compliance with these indicators.

It is expected that these public decisions will demotivate some doctors. Therefore, it is essential to develop a local program to motivate medical workers of municipal utility non-profit organizations to achieve the performance indicators. It is worth noting that this program may not necessarily include financial incentives, but certain awards of the mayor, free internship programs, invitations to attend cultural events, symbolic gifts, etc. It is assumed that the above prepare employees of public utilities to approve indicators of medical care quality to establish strict control over their implementation at the state level.

Furthermore, nowadays, there is an urgent strategic problem in state and municipal governments of Ukrainian health care. It is leaving out the health care system of all medical institutions and insufficient funding for medical care per patient. For example, several medical areas were left out of funding, such as bacteriological research, examination of certain population categories for alcohol intoxication, medical registration, and conscription. In preparation of documents for health care reform, the powers of local selfgovernment bodies and the state were not differentiated. That results in the inability to forecast budgets at local levels and ensure the population's rights to an adequate level of medical care. On the other hand, a significant percentage of the funds received for the payment of medical services from the National Health Service of Ukraine is used to co-finance preferential programs guaranteed but not financially supported by the State. This aspect is certainly demotivating in the work of health care workers.

Following the mentions above, the study proposed to implement the following recommendations at the country level:

- collecting and analyzing data on medical care components needed adjustment;

- creating working parties involving the specialists in research and practical medicine, specialists in economics, law, etc.;

- developing drafts of normative legal acts, coordinating and promulgating to establish by the legislation;

- adopting regulations and approving material and financial resources to ensure the effective implementation of the adopted terms;

- implementing the adopted terms, monitoring their compliance;

- preparing and adopting relevant legal acts at the local level;

- adjusting the activities of health care facilities.

In turn, it is necessary to highlight the measures aimed to improve the motivational processes for health workers by the management levels: 
- at the state level: increasing the capitalization rate in calculating the cost of medical services for the patient; approval of $100 \%$ financing of adopted preferential programs;

- at the local and state levels: developing indicators of medical delivery quality and their approval;

- at the local level: developing a local motivational program for employees of municipal utility nonprofit enterprises to implement quality performance indicators;

- at the enterprise level: introducing different motivational models based on an in-depth analysis of the institution's financial activities.

To determine the remuneration model that is the most effective in a particular medical institution, it is necessary to estimate the rate of remuneration. Thus, it would establish how much money the institution could allocate to pay its employees (Fig. 4).

It is worth mentioning that in 2017, several laws of Ukraine were adopted to regulate budget issues of health care institutions: the Law of Ukraine «On Amendments to the Budget Code of Ukraine» dated 07.12.2017 № 2233-VIII, the Law of Ukraine «On Amendments to Certain Legislative Acts Of Ukraine on improving the legislation on the health care institutions activities» from 06.04.2017 №2002, the Law of Ukraine «On state financial guarantees of medical care» from 19.10.2017 № 2168-VIII, etc.

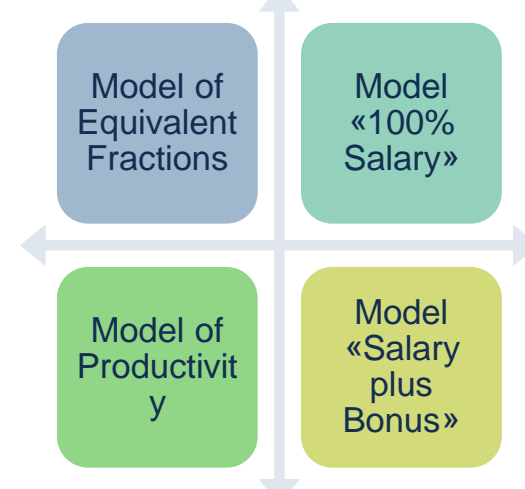

Figure 4. Determining the most optimal model of medical staff motivation under health reform Sources: developed by the authors.

Summing it up so far, it should be emphasized that the health care reformation in Ukraine changes the health care system and creates favorable conditions for effective employee motivation. It stands to mention that Vroom's expectancy model and Porter-Lawler's model are to be the most applicable during the reform and after health reforming. Following these models, the doctors expect and receive timely and fair remuneration based on the effort invested.

On the other hand, Adams' model would receive the value. Under this model, the doctor's remuneration depends on the quality of the doctor's work, not the positive or negative attitude of the institution administration. In turn, it is expected the participatory management model would be implemented. It would eliminate any illegal manipulation of public funds, increasing the doctors' selfesteem and performance efficacy of their colleagues.

Conclusions. The study findings showed that introducing motivational models in health care facilities requires consideration of the following aspects:

1) salaries of medical workers must comply with their knowledge, qualifications, efforts, and level of responsibility; 
2) the salary is not the main motivating factor in the case of gaining in experience and age of medical workers;

3) the main motivating factor for doctors is the recognition of their professional success;

4) the main motivating factor for nurses is involvement in the common cause.

The obtained results indicated that material incentives significantly form high doctor welfare and allow them to feel job satisfaction, society respect, increases their self-esteem, etc.

The authors proved the need to develop quality performance and their approval at the local level and the parallel development of a local program to motivate utility non-profit enterprises to implement quality indicators. Therefore, based on the mentioned above, the development of the motivational model medical field should reduce «casual laborer» as possible in medicine while appreciating those who came «answering the call of the heart».

Author Contributions: conceptualization, methodology, formal analysis, investigation, resources, A. M., H. D.; writing-original draft preparation, A. M.; writing-review and editing, lu. M.; visualization, Iu. M.; supervision, project administration, lu. M. All authors have read and approved the final manuscript.

Funding: This research received no external funding.

\section{References}

Bogoyavlenska, Yu. V. (2004). Effective mechanisms of work motivation. Economics: problems of theory and practice. Dnepropetrovsk: DNU, 195 (2), 528-539.

Kjellström, S., Avby, G., Areskoug-Josefsson, K., Andersson Gäre, B., \& Andersson Bäck, M. (2017). Work motivation among healthcare professionals. Journal of Health Organization and Management, 31(4), 487-502. [Google Scholar] [CrossRef]

Korlén, S., Essén, A., Lindgren, P., Amer-Wahlin, I., \& von Thiele Schwarz, U. (2017). Managerial strategies to make incentives meaningful and motivating. Journal of health organization and management, 31 (2), 126-141. [Google Scholar] [CrossRef]

Law of Ukraine «On Amendments to Certain Legislative Acts of Ukraine Concerning the Improvement of Legislation on the Activities of Health Care Institutions» of April 6, 2017 №2002. Retrieved from [Link]

Law of Ukraine «On state financial guarantees of medical care» from 19.10.2017 № 2168-VIII. Retrieved from [Link]

Law of Ukraine «On Amendments to the Budget Code of Ukraine» from 07.12.2017 № 2233-VIII. Retrieved from. [Link]

Luu, T. T., Rowley, C., Dinh, C. K., Qian, D., \& Le, H. Q. (2019). Team creativity in public healthcare organizations: The roles of charismatic leadership, team job crafting, and collective public service motivation. Public Performance \& Management Review, 42(6), 1448-1480. [Google Scholar] [CrossRef]

Mcdonald, E., \& Spence, C. (2016). Professions and Financial Incentives. In Routledge Companion to the Professions and Professionalism. Routledge. [Google Scholar]

McDonald, R., Harrison, S., Checkland, K., Campbell, S. M., \& Roland, M. (2007). Impact of financial incentives on clinical autonomy and internal motivation in primary care: ethnographic study. BMJ, 334 (7608), 1357. [Google Scholar] [CrossRef]

Razee, H., Whittaker, M., Jayasuriya, R., Yap, L., \& Brentnall, L. (2012). Listening to the rural health workers in Papua New Guinea-the social factors that influence their motivation to work. Social science \& medicine, 75(5), 828-835. [Google Scholar] [CrossRef]

Toode, K., Routasalo, P., \& Suominen, T. (2011). Work motivation of nurses: A literature review. International Journal of Nursing Studies, 48 (2), 246-257. [Google Scholar] [CrossRef]

Tynan, A., Vallely, A., Kelly, A., Kupul, M., Neo, J., Naketrumb, R., ... \& Hill, P. S. (2013). Sociocultural and individual determinants for motivation of sexual and reproductive health workers in Papua New Guinea and their implications for male circumcision as an HIV prevention strategy. Human resources for health, 11(1), 1-14. [Google Scholar] [CrossRef]

Valdez, C. D., \& Nichols, T. W. (2013). Motivating healthcare workers to work during a crisis: A literature review. Journal of Management Policy and Practice, 14(4), 43-51. [Google Scholar]

Vavylov, V. (2014). Motivation of medical staff. Vavy'lov Blog [Link]

Vroom, V.H. (1964). Work and Motivation. New York: Wiley.

Алла Мамай, Сумський державний університет, Україна

Юлія Мирошиченко, к.е.н., доцент, Сумський державний університет, Україна;

Хенрик Дзвіголь, доктор економічних наук, професор, Сілезький технологічний університет (Польща)

Мотиваційні моделі менеджменту та досвід ї упровадження в закладах охорони здоров'я 
A., Mamay, Iu., Myroshnychenko, H., Dzwigol. Motivation Management Model and Practical Realization Within the Health Care Institutions

Мотивація медичних працівників набуває особливого соціального значення, оскільки якість їх роботи впливає на здоров'я окремих громадян та здоров'я нації в цілому. Органи державного та муніципального управління повинні приділяти достатню увагу даному питанню. Метою статті $\varepsilon$ визначення основних напрямків і рекомендацій щодо побудови мотиваційних моделей менеджменту в закладах охорони здоров'я. У ході дослідження розкрито сутність та завдання управління кадровою політикою у закладах охорони здоров'я та проаналізовано основні методи мотивації медичних робітників. Оцінено вплив медичної реформи на мотивацію медичних працівників. Особлива увага приділена дослідженню нормативно-правової бази економічної та неекономічної мотивації в закладах охорони здоров'я. Методологічною основою дослідження стали такі методи обробки даних: порівняльний аналіз, метод наукової абстракції, індукції та дедукції, аналізу і синтезу. Для аналізу предмету дослідження використано інструментарій онлайн-сервісу Google Ngram Viewer та сервісу для аналізу наукових досліджень міжнародного рівня SciVal. За результатами аналізу запропоновано шляхи вдосконалення мотиваційних моделей менеджменту. Доведена необхідність розроблення індикаторів якості надання допомоги, їх затвердження на місцевому рівні. Автори прийшли до висновку щодо необхідності паралельного розроблення місцевої програми мотивації працівників комунальних некомерційних підприємств за виконання маркерів якості. Дана програма може містити відзнаки міського голови, безоплатні програми стажування, запрошення до відвідування культурних заходів, символічні подарунки тощо. У дослідженні наголошено на актуальності стратегічної проблеми у сфері державного та муніципального управління у сфері охорони здоров'я України, а саме неврахування всіх напрямків діяльності медичних закладів при рефрормуванні системи охорони здоров'я, а також недостатнє фінансування витрат лікувального закладу на надання допомоги в розрахунку на одного хворого. Результати проведеного дослідження можуть бути корисними для органів державного та муніципального управління України у сфері охорони здоров'я при розробці програм мотивації медичних працівників та їх утримання.

Ключові слова: мотиваційна модель, заклади охорони здоров'я, реформування, менеджмент, медичні працівники. 